\title{
Translation of Culture-Specific Fixed Expressions and Swear Words in Some Arabic-into-English Subtitled Films
}

\author{
By
}

\author{
Dr. Hamdi Ebeid Khalil \\ Lecturer of Linguistics \\ Faculty of Arts, Suez University
}

DOI: 10.21608/jfpsu.2021.68565.1056 


\title{
Translation of Culture-Specific Fixed Expressions and Swear Words in Some Arabic-into-English Subtitled Films
}

\begin{abstract}
This paper presents the concept of audiovisual translation (AVT) as it has only recently become an object of interest within the discipline of translation studies. The rise of new technologies has greatly shifted attention and focus from stereotypes of translation to technological and digital aspects of translation. This gives rise to international and intercultural communication and therefore, a dire need arises to investigate audiovisual translation that is considerably linked to socio and intercultural differences and norms. This paper intends to analyze subtitling as the most familiar type of AVT through taking into account important factors including sociolinguistic elements, cultural contexts, and stylistic considerations. The paper discusses film subtitling with the aim of exploring translator's conformity to the socio and cultural considerations when conveying the source language (SL) messages to the target language (TL). It mainly investigates the difficulties involved in subtitling language-specific idioms and swear words. The paper reveals that AVT should be based on cross-cultural awareness and a full comprehension of the cultural aspects of both the source and target languages. The paper also concludes that handling the translation of subtitles has specific characteristics and poses challenges that entail special attention to its transfer and the translation strategies applied in this regard.
\end{abstract}

Key Words: audiovisual translation, subtitles, translation strategy, fixed expressions, swear words. 


\section{ترجمة التعبيرات الثابتة وألفاظ السباب ذات الخصوصية الثقافية في بعض الأفلام المترجمة من العربية إلى الإنجليزية}

المستخلص

يتناول هذا البحث مفهوم الترجمة السمعية البصرية كإحدى مجالات دراسات الترجمة التي لم تلق اهتماما إلا في الآونة الأخيرة. ومع ظهور تقنيات جديدة، تحول الانتباه والتركيز بصورة ملحوظة من الأشكال النمطية للترجمة إلى الجوانب التكنولوجية والرقمية للترجمة، وهذا يؤدي إلى التواصل الدولي والتواصل بين الثقافات، ولذا تدعو الحاجة لتناول الترجمة السمعية البصرية التي ترتبط بشكل كبير بالاختلافات والمعايير الاجتماعية البينية للثقافات. ويهدف هذه البحث إلى تحليل ترجمة الحوار باعتبارها أكثر أنواع الترجمة السمعية البصرية شيوعاً من خلال مراعاة عدة عوامل مهمة منها العناصر الاجتماعية واللغوية والسياقات الثقافية والاعتبارات الأسلوبية. ويناقش البحث ترجمة الحوار بهدف اكتشاف مدى مطابقة المترجم للاعتبارات الاجتماعية والثقافية عند نقل رسائل لغة المصدر إلى لغة الهدف. ويفحص البحث بشكل أساسي الصعوبات التي تتطوي عليها ترجمة التعبيرات الثابتة وألفاظ السباب ذات الخصوصية الثقافية. ويوضح البحث أن الترجمة السمعية البصرية يجب أن تستند إلى الوعي عبر الثقافات والفه الكامل للجوانب الثقافية لكل من لغة المصدر ولغة الهدف. كما توصل البحث أيضاً إلى أن معالجة ترجمة الحوار لها خصائص محددة وتشكل تحديات تستلزم اهتماماً خاصاً بنقلها واستراتيجيات الترجمة المُطبقة في هذا الصدد.

الكلمات المفتاحية : الترجمة السمعية البصرية، ترجمة الحوار، استراتيجية الترجمة، التعبيرات الثابتة ، ألفاظ السباب. 


\section{Introduction}

Translation, being the process of conveying messages across linguistic and cultural barriers, is a primarily communicative activity. Translation is described by Farb (1981, p. 277) as 'a busy intersection at which at least five thoroughfares meet:the two languages, the cultures of the two communities and the speech situation in which the statement is uttered'. Each language reflects sociocultural concepts which have been crystalized over time. The translator has to accurately convey the meanings and ideas of the source language text (SLT) into the target language text (TLT). One of the most prominent difficulties and problems faced by the translator is how he/she copes with the cultural norms in the source language (SL) and finds the most apt strategy of accurately conveying these cultural aspects into the target language (TL).These problems are due to cultural and linguistic gaps between the two languages. Toury $(1995$, p.38) expresses this fact stating that "the differences between cultural norms of different countries rise up through using language and translating from language to another, especially during subtitling because it deals with audiovisual materials". To achieve this goal, a translator should be well-versed with the social and cultural ethos of both languages. Translation should not be viewed as a linguistic activity here but it is a cultural one as well and the text's function may be changed when they are translated (Diaz Cintas and Remael, 2010).

The present paper approaches a special mode of translation, namely, audiovisual translation (AVT) which is a specialized branch of translation characterized by the interaction of text (whether oral or written) with sound and image. Audiovisual content can be used either at the production or post-production stage. The three most popular types of audiovisual translation are dubbing, subtitling and voice-over and. Dubbing is a type of audiovisual translation which involves replacing the soundtrack of the source text containing the actors' dialogue with a target language soundtrack that reproduces 
the original message, in a way that the target language sounds and the actors' lip movements are synchronized. (Diaz Cintas, 2009).

Subtitling is the written translation of the spoken language of a television film or series into the language of the viewing audience. It is, as (Shuttleworth and Cowie, 2004, p. 61) observe, "A[a] term used to refer to one of the two main methods of language transfer used in translating types of mass audio-visual communication such as film and television". Subtitling is also defined, according to Gottlieb (1997, p.95), as "diasemiotic or intermodal form of audiovisual translation as it involves the shift from a spoken to a written medium".

Subtitles usually appear and disappear in correspondence to the original dialogue part and are attached to the image on the screen later as a result to post-production part. The translated text usually appears in one or two lines at the foot of the screen synchronously with the dialogue or narration in the source language. The main function of subtitles is to perform their role within this polysemiotic environment. Subtitling enjoys some advantage over dubbing, as "an expensive, quick, foreign-culture friendly and generally fairly politically correct mode of screen translation" (O'Connell, 2007, p. 67).

Voice-over is the replacement of the original dialogue's voices by other voice track in the TL. Revoicing is viewed by Perez Gonzalez (2014, p.19) as "a generic term encompassing a range of spoken translation methods, including simultaneous interpreting, free commentary and narration". The present paper focuses only on the second type, i.e. subtitling as it is closely related to informing viewers in particular and people in general of cultural variations and norms of countries and languages. The two main types of subtitling according to linguistic parameters are interlingual and intralingual. The former is subtitling between two languages whereas the latter is subtitling within the same language (Bartoll, 2004), (Gottlieb, 2005) 
and (Diaz Cintas, 2006). It is to be noted that interlingual subtitling is the concern of the present study since it involves a transfer of a spoken discourse to a written text between source and target languages.

The present paper approaches subtitling by analyzing two culturebound aspects i.e. idiomatic expressions or proverbs and swear words that have peculiar linguistic characteristics. They are defined as linguistic units whose meaning cannot be construed individually but at the level of the whole structures. In other words, idioms are conventionalized which means that their meaning cannot be predicted on the basis of knowledge of the independent conventions that determine the use of their elements when they appear in isolation. Idioms and fixed expressions, according to (Baker, 1992, p. 63), are "frozen patterns of language which allow little or no variation in form and, in the case of idioms, often carry meanings which cannot be deduced from their individual components". She (1992, p. 63) further illustrates that idioms allow "no variation in form under normal circumstances" and that a translator cannot do any of the following with idioms:

1-Change the order of the words of an idiom. The way the words are put together are fixed and cannot be changed. E.g. "it rains cats and dogs" not "it rains dogs and cats".

2-The word in an idiom cannot be deleted. E.g. "have a sweet teeth" not "have a teeth".

3-No extra words can be added to an idiom. E.g. "red herring" not "very red herring".

4- Replacement of a word by another is not allowed in an idiom. E.g. "no skin off your nose" not "no skin off your mouth".

5- The grammatical structure of an idiom cannot be modified. E.g. "kick the bucket" not "the bucket was kicked". 
The above restrictions and characteristics of idioms should be taken into account since they may affect the degree of idiomaticity of lexical items and remove the figurativeness deemed as the most intrinsic feature of idiomatic expressions. It can be added that nonsubstitutability of idioms distinguishes them from other multi-word combinations such as collocations and phrasal verbs that may allow several variations in their constituents.

Idioms are culturally bound in the sense that it is difficult to construe and interpret idioms without taking into account their cultural specificity. This means that idioms display features of the nature of its culture that include beliefs, social attitudes and customs. Idioms are classified into idioms of encoding and those of decoding (Makkai, 1972, p.25). The idioms of encoding are those idiosyncratic lexical combinations that have transparent meanings that can easily be understood and identified by non-native speakers. For example, the idiomatic structure to give green light which could

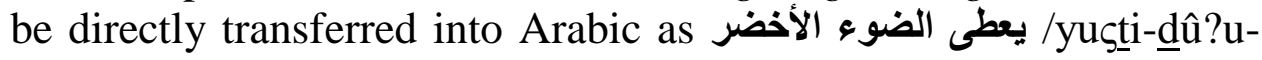
1?axdar/. This combination exhibits a total equivalence in function and form since the two idioms have the same components and bear the same meaning. Such idioms have cultural associations and backgrounds which make them easily comprehensible and their source may have been blended in both languages by time. The lexical items of idioms and the way these lexical items are organized are greatly influenced by the culture of each language. Having knowledge of both culture and the contextual situation is the clue for recognizing and construing idiomatic structures. This can be exemplified by the Arabic idiom هذا الشبل من ذاك الأسد /haða šiblu min ðâka-l?asad/ which can be expressed in English through using the idiom like father, like son to echo the aspects of resemblance that usually hold between fathers and their sons. It is part of the Arabic culture to use the word 'lion' in this combination which is not the case with English. Both languages differ in their selection of items but the same meaning is almost conveyed at the level of the two idioms. Likewise, English culture is interested in the word 'dog' so 
that it is used in such idioms as dog's chance, dog's breakfast, dog's life and let the sleeping dogs lie. These idioms have no counterparts in Arabic culture since these combinations are peculiar to English culture (Nasser, 2019, p.316). Such idioms which are highly specific to a particular cultural environment are called decoding idioms defined as those nonidentifiable and misleading lexical expressions whose interpretations could not be comprehended on the basis of only learned linguistic conventions.

\section{Methodology of the Study}

The study describes various subtitling conventions being followed. It is an evaluative-descriptive study concerned with analyzing a corpus of representative samples of Arabic spoken messages as a source text into English written messages as a target text. The study provides an analytical examination of difficulties and problems associated with translating Arabic fixed expressions and swear words into English in some selected subtitled films. The present study attempts a twofold task: to analyze the recorded data from a sociopragmatic point of view and then to evaluate the data from a translational perspective which identifies strategies adopted by subtitler in handling the data in question.

Translation of the selected data will be achieved through taking into consideration the context of situation and the notion of 'functional relevance' developed by Catford (1969, p.94). This notion highlights the sociolinguistic approach of translation, especially the translation of dialogue which is deemed highly contextualized in terms of culture and situation. The data analysis will give special focus to the cultural norms and variations of both the source language and the target language as an essential step towards the comprehensibility of the translated dialogue to the target audience. Following a lengthy discussion of subtitles, the study attempts to propose a more adequate subtitling that accords to the communicative effect of the translation theories. 


\section{Data Collection}

As far as the data is concerned, two films have been recorded. The first films is entitled /?asmâ/ "asmaa" which is an Egyptian drama film produced in 2011, written and directed by Amr Salama. It narrates the story of an Egyptian woman with HIV who struggles to live under the pressure of keeping her HIV under wraps. It is noted that the film is based on a real life experience of a woman that died of a burst gallbladder after doctors refused to operate on her due to her AIDS symptoms. The second film is entitled /tîr ?inta/ "You fly away". This is an Egyptian comedy film produced in 2009 and directed by Ahmed El-Gendy. The idea of this movie was based on the American movie "Bedazzled" as stated in the introduction to the movie.

The data represent Egyptian colloquial Arabic and exhibit different cultural norms in the Egyptian society. Data collection is mainly based on the fact that these two films contain scenes rich in samples of culture-specific fixed expressions and swear words that are highly contextualized. Data collection inherently follows a linguistic pattern that cultural backgrounds play an important role in the course of the idiom interpretation and translation. The collected data are purposefully intended to highlight that translation problems involve not only the linguistic and stylistic features but also the cultural and social variations between the SL and TL.

\section{Research Questions}

1-In what way are fixed expressions and swear words relevant to translating subtitles in terms of social and cultural variations?

2-What bearing do social, linguistic and stylistic considerations have on subtitling and how do they contribute to properly contextualized shifting of spoken messages to written ones? 


\section{Theoretical Framework \& Literature Review}

The analysis and assessment of fixed expressions and swear words is a culture-specific phenomenon. The Target Text (TT) is evaluated acceptable or unacceptable according to its conformity to SL message and whether it produces the same effect or not to the TT viewer. Therefore, the study examines the transfer of spoken message to written one and how far the screen translators managed to capture the sociocultural message that is compatible to the source language text.

Pragmatics is the discipline which is basically concerned with language use according the context of situation. Pragmatics is the study of meaning in relation to the context in which the person is speaking or writing. This includes social, situational and textual contexts. Therefore, the relationship between linguistic form and communication function is of central interest in the area of in pragmatics (Paltridge, 2006, p. 53).This holds true to what the prominent linguist Leech (1983) views the function of pragmatics. He (1983, p.6) sees pragmatics as "the study of meaning in relation to speech situations". It can be added that it is related to how language is manipulated by language users in different aspects of life. That is because the use of language varies from one user to another and naturally from one country to another.

The study gives extra attention to the pragmatic illocutionary force of fixed expressions and swear words over their elocutionary force. This prompts us to say that the subtitler must be acquainted with the target audience. In this problematic field of translation, emphasis is placed on transferring speech acts rather than on the superficial denotation of the utterance. The illocutionary force of fixed expressions and swear words stands for deep structure which intermediates between the source text and the translated message. Thus, pragmalinguistic approach is crucial to the rendition of these culture-specific aspects. It is important here to shed light on the 
types of meaning that are related to the domain of idioms and fixed expressions. Three types of meaning developed by scholars are relevant to this study, namely, situational, emotive and connotative. Situational meaning which expresses "the meaning of an utterance in a given communication" (Larson, 1984, pp.41-43). Emotive meaning that is called connotative meaning "deals with extra linguistic factors and the figurative meanings that a word may have" (Nida, 1964, p. 70). Connotative meaning "deals with a feeling or idea that is suggested by a particular word although it is not necessarily a part of that word's meaning" (Koller, 1995, pp.192-122).

Audiovisual translation is posing several challenges to TV translators who find it necessary to follow strict conventions and consistently translate according to a set of norms which are peculiar to each country. Translation using subtitles seems to be governed by translation norms and strategies proposed by linguists and theorists. Analyzing subtitled idioms and swear words in this study adopts mainly the classification of difficulties and strategies formulated by (Baker, 1992) along with strategies developed by some other translators and scholars as (Gottlieb, 1992) and (Schjoldager, 2008). These strategies will be manipulated in the section to come to pinpoint what strategy the translator opts for to fulfill the expectations of the target viewers.

Nida (1964, p. 226) has cited four components which determine the change involved in the process of transferring a message from the source language to the target language:

1-Adujstment of the form of the message to the requirements of the receptor's language.

2-Production of semantically equivalent structures.

3-Providing equivalent stylistic appropriateness.

4-Equivalence of communicative load. 
The first two components represent the linguistic relevance of the translated message. The first component involves the grammaticalstructural aspects whereas the second component includes semantic aspects. The third component stands for the stylistic-registerial and the fourth component includes the illocutionary aspects. In this study, great attention will be given to the functional relevance of the message, i.e. the illocutionary aspect as well as stylistic ones.

There are some previous studies conducted about challenges and difficulties related to translating subtitles. The descriptions of the previous research findings are as follows.

One of the studies was carried by Al Abwaini (2013). He conducted a study entitled Problems that Translators Face When They Subtitle Culturally-Bound Expressions from English into Arabic. This study seeks to achieve the following objectives:1) investigating the cultural challenges translators encounter in translating culturally-bound expressions from English into Arabic, 2) exploring the differences between the professional and the nonprofessional translators in subtitling and 3) proposing effective strategies and methods used in rendering these culture-bound expressions. The method used in this study was an empirical method where a sample of 40 graduate students and 40 undergraduate students enrolled in the English language programs during the academic year 2012/2013 was selected randomly from Jordanian Universities. The researcher has used two instruments: translation test and an informal semi-structured interview. The data for the study were taken from different scenes of three American films, namely, Scent of a Woman, Erin Brockovich and Casino. The findings based on the two instruments were that culturally-bound expressions proved problematic to translators who, in their turn, were short of using appropriate translation techniques in subtitling. Furthermore, literal translation results in inadequacy of the subtitled material and poor performance on the part of participants in translation test. 
In addition, Al-Kharabsheh and Yassin (2017) conducted a study entitled Translation of Colloquialism in the Arabic-into English Subtitled Film, The Dupes. The objectives of this study were 1) investigating problems and difficulties in subtitling colloquial expressions from Arabic into English, 2) identifying subtitling inaccuracies and 3) suggesting practical mechanisms that contribute to working out problems in subtitling. The method applied in data analysis was an evaluative descriptive method. The data for this study has been gathered from one source: the Dupes film acted in colloquial Arabic. It is a Syrian drama produced in 1972 based on Ghassan Kanafani's 1963 novel, 'Men in the Sun', which was converted into a film under the title of the Dupes. The main findings of this study were 1) colloquial expressions especially those that reflect religious orientations have not been subtitled properly, 2) the subtitler has completely dropped out some colloquialisms from subtitling and 3) a considerable loss of cultural aspects of meaning has been observed in subtitling some colloquialisms. The researchers proposed three strategies to overcome subtitling pitfalls such as fullcommunicative strategy, idiomatic strategy and literal strategy which is limited to shared cognitive backgrounds between the two languages and cultures in some certain contexts .

Another study was carried out by Hawel (2019). She conducted a research entitled Strategies of Subtitling Swear Words in the Wolf of Wall Street Movie. The objectives of this study were 1) shedding light on subtitling of swear words that constitute a difficult task for translators from English into Arabic in Terence Winter's The Wolf of Wall Street movie and 2) to find out strategies employed by the subtitler of this movie. The study employed quantitative method based on investigating different strategies applied in subtitling swear words and the number of those words that have been changed through rendering. The analysis of the data indicated that six strategies have been adopted by the subtitler, namely, deletion, softening, addition, literal translation, changing the semantic field and register shift. It was found that softening and deletion strategies 
are used to diminish the bad impact of insulting and vulgar language. Literal translation strategy was also resorted to by the subtitler to produce a similar effect on the target audience in some few cases. The study also concluded that the most frequent rate is given to deletion strategy, then to softening, register shift, change in the semantic field, addition and literal translation respectively.

There were some other studies pertinent to analyzing challenges and problems of subtitling from a cultural perspective. Most of these studies concentrated on one direction: English into Arabic. However, not enough research connected to translation of Arabic into English subtitled films has been conducted. Therefore, the researcher finds it proper to carry out the current study to fill the gap in this respect. It can be added that besides idiomatic expressions, this study intends to investigate another multi-word combination i.e. swear words, which may be not be given a due attention in other studies.

\section{Data Analysis}

\section{I-The First Film /?asmâ/ "Asmaa".}

\section{Example I:}

The doctor to Asmaa: إإنت مالك خايفة كده ليه/inti mâlik xâyfa kida leih/ "Why so frightened?.

.

. دي زي شكة الدبوس/di zay šakkiti-ddabûs/ "It’s just a pinprick".

Having a quick look at Example 1, we find that it is a conversational bit between a doctor and his female patient Asmaa trying to comfort her and assuring her that the medical procedure is going to cause only a minor pain. The Arabic fixed expression زي شكة الدبوس zay šakkiti-ddabûs/ is not limited to medical usage but it extends to other speech situations to connote the easiness, simplicity 
or accessibility of any procedures and the facility of whatever attempts made. It is noted that the word /šakkit/ collocates with the word /?addabûs/ "pin" to form an idiomatic and metaphorical meaning. The word 'pin' is denotatively a thin or sharp tool made usually of steel or copper and used to connect or install objects together but it is employed in this combination to have socio and cultural implications. This idiom literally means (any tiny or minute juncture or a very small hole made by a pin) while it carries idiomatic connotations such as 'the matter is not that complicated', 'it is not a big deal at all' and 'a very small amount of something'. Metaphorically, this idiom is used in English and Arabic cultures to describe a situation that inherently seems less thorny and problematic than people would think.

The subtitling that has been given to the idiom زي شكة الدبوس/zay šakkiti-ddabûs/ is "it's just a pinprick". The strategy the subtitler adopts here is using a word for word translation. This strategy entails using a nonidiomatic combination in the target language "it's just a pinprick" which may not adequately convey the meaning of the source language fixed expression /zay šakkiti-ddabûs/.That is because the nonidiomatic structure the subtitler provides is considered a literal interpretation and focuses on the semantic component rather than idiomatic or cultural content. It can be said that nonidiomatic expression may be judged acceptable provided that it could be functionally relevant and compensates for shifting idioms to nonidiomatic structures, otherwise, "the end result is a weakening of the figurative force of the translation, since translators do not compensate for loss of certain idioms by the introduction of others" (Nida and Taber,1982, p.106). Therefore, the subtitler's version is not sufficient to echo the cultural connotations of the source language text. In order to reflect a successful screen subtitling, it would be more effective and adequate if the colloquial idiom in question is translated as 'it is a minor annoyance', 'there is nothing to it', 'it is easy as $A B C$ ', 'it is easy as a pile' and 'it is a snap'. 
These suggested subtitles fully reflect the idiomatic and metaphorical aspects of this fixed expression.

\section{Example 2}

The chemist to Asmaa ده تاخديه بس بجر عة معينة هدالك /da taxdîh bas bigursa muşayynah hadihâlik/ "Take this in special dose".

/lazim taxdi bâlik min-lgurça kuwayis ?awi/ "Be careful".

(عشان لو زودتي الجرعة مكن تسافري tisâfri/"If you exceed the doses, you could go on a trip".

In example 2 above, the chemist is warning the patient not to exceed the prescribed dose, otherwise, grave consequences are bound to occur. The Egyptian colloquial fixed expression ممكن /momkin tisâfri/ literally means (you may go on a trip). It is associated with the conception of departure or leaving a certain place and moving on to a new destination. Taking the contextual situation of this film scene into consideration, it turns out that this expression is best interpreted metaphorically and does not make any sense if the literal interpretation takes over. Idiomatically speaking, Arabs use this expression to indicate something beyond its literal application, i.e. moving to the other world. In other words, in its immediate context, this expression is pragmatically oriented. Its illocutionary force in Arabic culture is relevant to the idea of death or terminating one's life as a result to administering overdose of medication.

The expression ممكن تسافري/momkin tisâfri/ is a colloquial Egyptian expression that the subtitler may encounter a problem in translating into English and consequently the target text (TT) viewer may lose the pragmatic effect of this utterance. This expression has been given the subtitling "you could go on a trip" which seems too literal to be functionally relevant in capturing the contextual meaning. Such subtitling has nothing to do with the concept of 
losing one's life and so the TT viewer finds it hard to obtain the idea of life termination through the expression ممكن تسافري /momkin tisâfri/. That is because literal translation is translating an idiom by giving a word-for-word translation of the source language idiom, which most of time results in unnatural or wrong rendering of idioms (Newmark, 1988). A more effective and impressive subtitling of this expression would be 'you could pass away' and 'you could be finished off'. The difference between these two English expressions is that the former is used by way of euphemism whereas the latter is not. It can be said that the target language has no corresponding equivalent idiomatic form with the same connotation as that of the source language, but the subtitler may resort to other idiomatic forms in the target language to express the implied meaning. So, other suggested subtitles of the expression at hand would be at the level of the target language idioms 'you could kick the bucket', 'you could meet your end', 'you could breathe your last' and 'you could go the way of all flesh'. Considering these suggested subtitles, the communicative load of this colloquial expression would be adequately conveyed to the (TT) viewers.

\section{Example 3}

Sayed to Asmaa: محش مالي عينك ولا إيه /maћadiš mâli çainik wala ?eih/ " Don't you respect anyone"?

Mosaad: إيه يا حاج سيد مالك؟? /eih ya hâjj Sayyid mâlak/ "What is it"?.

Asmaa: ماله ده إيه؟ /mâlu da ?eih/ "Who cares"?.

intu haticmilu şalaiyya farah wala ?eih"/ "Are you ganging up against me"?.

This film scene narrates an argument between the same female patient Asmaa before she catches AIDS and an old man approaching her to buy some carpets in the market. Once told the price, the old man expresses his refusal and offered a lower price and the female 
seller did not reply. So, he gets upset and shouted at her. Another man intervened and asked the old man why he is so furious.

The above scene contains two Arabic colloquial expressions that may be hard to be subtitled into the target language. The first fixed expression is محش مالي عينك/maћiš mâli çainik/ which literally means (would not anyone fill your eyes?). Culturally speaking, it is the customs of Arabs to rebuke the person to whom such a colloquial expression is addressed. This means that whoever such an idiom is ascribed to shows no reverence or regard to others or is characterized by being arrogant or big-headed. It is also used in situations when talking about insensitive people with an exaggerated sense of selfworth or self-centered.

In the Arabic culture, the word / cayn/ "eye" is used as a symbol of appreciation and holding someone in high esteem. In other words, it is used in contexts where someone has a complete conviction or impressed by someone else or something. There are some certain combinations in which the word/cayn/ "eye" collocates with the Arabic verb /mala?a/ "fill" to form the idiomatic expression /mala?a cayni/ where the speaker here is metaphorically implying that the person or the thing spoken of is greatly up to his expectation or his persuasive faculties. On the contrary, when the word / cayn/ "eye" collocates with the Arabic verb /saqata/ "fell" to constitute the expression /saqata min çayni/, it idiomatically refers to the idea of falling short of somebody's expectations and appreciation or when someone went down in my estimation or my opinion.

Translationally speaking, the subtitler gives as an equivalent to the expression محش مالى عينك /mahdiš mâli çainik/ the clause "don't you respect anyone"?. The strategy the subtitler adopts in translating this expression is adaptation through paraphrasing the source language fixed expression which has no equivalent in the target language. However, this strategy is culturally and idiomatically inadequate since it overlooks the idiomatic and cultural implications 
of this fixed expression. This subtitling is considered undertranslation since it does not include all the essential components of the source language fixed expression. Thus, the idea of respect in this subtitling does not sufficiently convey important features of Arabic cultures in this regard as it basically connotes the idea of conceit, disdain and being haughty. Therefore, the suggested subtitling for this expression could be 'you are so stuck up !', 'you are full of yourself' and 'you are a big-headed'. These suggested subtitles reflect the communicative load and maintain the sociocultural shades of meaning.

The second fixed expression in this scene is تصعلوا على فرح ولا إيه /haticmilu calaiyya farah wala ?eih/ (lit. are you going to make a wedding on me?).This idiom can be challenging in subtitling as it requires full understanding in order to be accurately conveyed in the TL. This expression is used to describe situations of making mockery of someone or holding him up to ridicule in the Arabic culture. It is used when two or more persons ally against somebody to make him an object of fun and mockery, usually by verbal interaction and not by bodily intervention.

This expression is subtitled as "are you ganging up against me"? which does not seem to be relevant in this context as there is a far cry between ganging up against and making somebody an object of ridicule. The idea of ganging up against is not the actual meaning of this fixed expression, rather, it is the idea of belittling somebody that is the intended meaning that goes in line with the cultural aspects of this idiomatic expression. A more reflective equivalent to this Arabic colloquialism that can convey the meaning idiomatically and metaphorically would be 'are you making mockery of me?', 'are you making fun of me?', 'are you poking fun at me?' and 'are you playing dirty?'. It must be emphasized here that the same contextual and cultural meaning is displayed by the Arabic Colloquialism هتحفلوا على /hathafilu calaiyya/ (lit. are you going to give a party on me?). Culturally, this holds true to situations where there is a deliberate 
alliance on part of some to make someone an object of laugh and sarcasm either with the purpose of criticism or fun.

\section{Example 4}

Aiten to Asmaa: إنتى حالتاك ممكن تقلب الدنيا /?inti ћâltik momkin t?libddunia/ "Your case will cause uproar".

التعطيات فتيلة ممكن يحصل إيه لو طلعتي في التليفزيون وقلتي إن إنتى اترميتى من أوضة

/?inti mutaxayilah momkin yiћșal ?eih law tiliçti fi-tilivizyun wi ?ulti ?in ?inti ?itramaiti min ?uditi-lşamaliyât fi-ššâriç/ "Imagine what happens if you go on TV and say you have been thrown out of the operation room".

In this scene, the TV station representative Aiten is trying to persuade the patient to go on a TV talk show to recount the problems and humiliating conditions she has been going through due to doctors' reluctance to operate on her. That is because the patient strongly refused to go on TV as she thinks this as a stigma that will haunt her reputation among relatives and members of society.

The Egyptian colloquialism تقلب الدنيا /t?lib-ddunia/ (lit. to upside down the world) is a problematic culture-bound fixed expression as to its subtitling. Arabs manipulate this idiom to express the widespread repercussions of a specific issue among different societal sections and institutions. Therefore, when this expression is used, the speaker is pragmatically intending to impute to the hearer that the issue at discussion is bound to yield echoed responses and immediate results at the short-run. The subtitling given to this expression is "your case will cause uproar". The subtitler adopts a semi-communicative strategy in translating this expression which is deemed acceptable. However, this strategy does not seem to fit well in this context as it does not adequately highlight the Arabic culture in this respect and overlooks the idiomatic meaning. The word 
'uproar' is usually related to spatial commotion and violence. It is, as Webster's Ninth New Collegiate Dictionary (1990) observes, "a state of commotion, excitement, or violent disturbance". It does not reflect the Arabic culture concept of attracting attention to certain issues either to gain unanimous support or condemnation.

On the other hand, the target language contains similar idiomatic forms with corresponding metaphorical meaning as the case with the source language idiom تقلب الدنيا /t?lib-ddunia/.This prompts us to say that the subtitler had to resort to the strategy of total equivalence i.e. finding an idiom with a similar meaning and form in the target language in order to reflect the cultural meaning. Culturally, English employs the idea of making something resounding and having a great momentum at the level of some idiomatic expressions. For this reason, a more reflective and indicative equivalent subtitling of the source language expression would be 'your case will turn the world head over heal', 'your case will turn the world over' and 'your case will turn the world on its head'.

\section{Example 5}

Asmaa: أنا مش جاية أثحت با محسن بيه /?ana miš gâyya ?ašћat ya Muћsin baih/ "I'm not begging Mr. Mohssen".

Mohssen: معلش با مدام حقلك عليا /maçališ ya madâm ha??ik çalaiyya/ "Excuse me madam. I am sorry".

Mohssen:أنا كده لساني متبرى منى على طول و عاملي مشاكل /ana kida lisâni mitbarri mini ̧̧ala tûl wi çamilli mašâkil / " I babble all the time and this causes me a lot of embarrassment".

This scene is an argument by Mohssen who is strongly criticizing persons infected with AIDS because of their fear of speaking out suffering, bad conditions and being marginalized by society and consequently they do not deserve to be defended by the programme. Asmaa is greatly offended by Mohssen's statement. 
The fixed expression لسانى متبرى منى /lisâni mitbarri mini/ (lit. my tongue is tinged with me) is a culture-bound idiomatic expression. It has no equivalent in the target language and the subtitler might have difficulty subtitling it in the target language. From a cultural point of view, Arabs used this expression to refer to problems and embarrassing situations the person my get involved in or go through as a result of lacking control of his tongue. That is primarily due to the fact that this colloquial Arabic expression is linked to statements uttered in specific situations and may yield undesirable and counterproductive effects. Culturally and customarily speaking, the word /lisân/ "tongue" in certain Arabic combinations may be an indication of solemnity, sagacity, wisdom and reverence as عفيف اللسان/rasînu-lisân/. On the contrary, it may be used to symbolize negative qualities such as irresponsibility, being talkative and unreliability as the case with the fixed expression under discussion.

As for the subtitling of this Arabic expression, the subtitler provides "I babble all the time". The semantic adjustment adopted here in subtitling this expression, as (Nida and Taber, 19982, p.162) put it, is shifting "idioms to nonidioms". This shift does not seem proper to the Arabic culture nor reflects the idiomatic meaning. It does not echo the true image of the Arabic expression as the TT viewer cannot grasp the intended meaning given by this subtitling. The word "babble" in this context may not be the better choice on the part of the subtitler to do the original meaning of this Arabic expression. The word "babble", according to Longman Dictionary of Contemporary English (1995), means [1]: to speak quickly in a way that is difficult to understand or sounds silly ; [2]: to make a sound like water moving over stones". Thus, this combination is not indicative to the TT viewer and is not accurately contextualized. A suggested subtitling of the Arabic expression in question would be 'I do not hold my tongue', 'I do not always bite my tongue off', 'I am a vulgar' and 'I have unbridled tongue'. The idiomatic expressions "hold your tongue" and "bite your tongue" mean, according to 
Collins COBUILD Dictionary of idioms (1995), "you do not say a particular thing, even though you want to or are expected to, because it would be the wrong thing to say in the circumstances, or because you are waiting for a more appropriate time to speak". These suggested subtitles are fitting the contextual situation and present the true image of this culture-bound fixed expression.

\section{Example 6}

Mohssen:ما كل واحد يقولك و انا مالى إنمعنا انا:ma kull wâhid u?ulik wa ?ana mâli ?išmiçna ?ana/ "Everyone asks why is it my business? Why me?".

Mohssen: مشكلة كل المصرين/muškilit kulli-lmaśryyîn/ "It's the same with Egyptians".

Mohssen: محدش عايز يقف في وش المدفع /maћadiš câyiz yu?af fi wišilmadfaৎ/ "No one wants to stand before the barrel of a gun".

This scene includes a conversation between Mohssen (TV presenter) and Asmaa where he tries to convince her to recount the suffering and difficulties she has gone through with her disease on a TV talk show. She is still hesitant to appear on TV with her face and voices her fears just as the case with many patients with the same disease. Mohssen expresses his anger that no one would like to take the risk to make the issue publicly known, especially to the authorities concerned in order to be addressed and settled. Mohssen used the Colloquial Arabic fixed expression يقف في وش المدفع /yu?af fi wiši-lmadfac/ literally meaning (stand in front of a cannon). In the Arabic culture, this is an interesting colloquialism that is used when taking about a great risk of doing something that others are reluctant to take either because of apprehension of being getting involved in problems and difficulties or of being coward. It is also used in situations to show that someone is willing to fight, take on a challenge, argue or compete with someone else to achieve something 
that seems difficult but necessary. This expression is always related to urging someone to take the initiative to take the first and sometimes risky steps toward accomplishing something.

The colloquial expression يقف في وش المدفع/yu?af fi wiši-lmadfas/ is an idiomatic-metaphorical colloquial Arabic expression that may give rise to subtitling awkwardness since it has both a metaphorical image and an idiomatic meaning. The subtitling given to this expression is "No one wants to stand before the barrel of a gun" which seems too literal and odd to convey the Arabic image of obtaining something and making it heard at a large scale. This subtitling may not help the viewer to fully capture the cultural aspects of this Arabic colloquialism.

Therefore, some other subtitles that may match the source text can be proposed such as the target language idiomatic forms 'no one wants to take up the slack', 'no one wants to be at the coalface', 'no one wants to take up the cudgels', 'no one wants to take up the gauntlet', 'no one wants to be under gun' and 'no one wants to walk point'. These idiomatic structures may carry the full communicative content and may keep the socio-cultural overtones of this colloquialism.

\section{Example 7}

The guest: أجسام الطلبة مبتقبلش التطعيمات /agsâmi-ttalaba mabti?balštatçimât/ "Their bodies do not accept vaccinations".

Mohssen:و واضح إن العيب في أجسام الطلبة مش كويسة مبتقبلث التطعيمات ?ini-lçaib fi ?agsâmi-ttalaba miš kuwayisa mabti?balš-tatcimât/" The problem is with our children's bodies. They're not healthy enough. They cannot tolerate the vaccines".

Mohssen: يققى إحنا نعدم الطلبة بقى لأن أجسامهم زبالة /yib?a ?iћna nicdimittalaba ba?a la?in ?agsâmhum zibâla/ "So let's execute the students , their bodies are so weak, right?". 
Asmaa's father watching TV: تاك نيلة في تقل دم أمك /tak nîla fi tu?1 dam ?ummak/ "You jerk".

This is a TV programme handling the issue of vaccinating students with diseases. Mohssen is hosting a medical expert that denies administering vaccinations to students because their bodies cannot tolerate the vaccinations. Mohssen used to make mock of the guest's statement as an indication of refuting what he said.

This scene contains one of the most popular Egyptian colloquial swear words تاكك نيلة فى تقل دم أمك /tak nîla fi tu?l dam ?ummak/ which literally means (your mother's heavy blood). Culturally speaking, this expression is used as a term of insulting and degradation. It is usually used in contexts where the person to such an expression is attributed is unbearable and boring as a result of his deeds or statements. It is noted that the expression under discussion is composed of two swear words; the first part is:تاك نيلة /tak nîla/ which can also be pronounced in some Egyptian colloquial dialects as جاتك نيلة /gâtak nîla/. Both varieties of the same swear word is roughly equivalent to "go to hell" whereas the second part is: تقل دم أمك /tu? dam ?ummak/. It may be the case that the two parts are used together or each part may be used per see and still indicating insult or offence. Nevertheless, the same fixed expression is not necessarily limited to situations where it is used in terms of insulting, but it extends to other non-insulting or humorous situations among close friends or relatives.

The subtitling that was given to this culture-specific swear word is "you jerk". The subtitler gave no subtitling for the first part of this expression تاك نيلة /tak nîla/ as he/she decided to drop it by following deletion strategy, partly because he/she sees it marginal to the contextual situation or his/her lack of knowledge of the cultural component of this expression. Deletion here is realized at word level in the sense that only part of the swear word is omitted (Schjoldager, 2008). The subtitler's dropping of this subtitling may not help the TT 
viewer to grasp this colloquialism which is frequently used in insulting situations. In addition, the subtitling "go to hell" should not be overlooked in this context as it is inherent colloquialism in the source language and does not carry any tabooed aspects of meaning in the target language.

For the second part of this expression تقل دم أمك /tu?1 dam ?ummak/, the subtitler provides the phrase "you jerk". This subtitling is not expected to convey the communicative load implied by this expression. The word "jerk" means, according to Webster's Ninth New Collegiate Dictionary (1990), "a stupid or foolish person". The idea of stupidity and foolishness has nothing to do with the Arabic culture of this colloquialism. The word "jerk" carries other connotations that might be far from the intended meaning of the phrase دمه تقيل خفيف /damu t?îl/, the opposite of دمه /damu xafîf/ which is equivalent to "he's fun to be around". The suggested subtitles of this expression are 'you boring, unbearable', 'you insufferable, unpleasant' and 'you disagreeable'. These suggested subtitles are relevant to the Arabic-idiomatic colloquial swear word and to the contextual situation of the film scene.

\section{II- The Second Film : / tîr ?inta/ "You Flay Away!"}

\section{Example 1}

\section{Baheeg to the shop assistant:}

أنا عايز قميص يكون روش أخر حاجة ?ana ̧âyiz ?amîs yukûn riwiš ?âxir hâga/ "I would like a shirt that's the latest trend and cool".

و ويكون بالبلدي شكله ستايلش وكالرفول وشكله فخم وغالى هرشت الليلة؟ bilbaladi šaklu stayliš wi kalarful wi šaklu fixim wi gâli haraštlailah/ 
"I want a shirt and to use the common slang," stylish " and "colorful" with expensive brand name. You with me (Egyptian slang)"?.

Shop assistant: يا هلا بيك ده احناز ارنا النبي /ya hala bîk da ?iћna zarna nnabi/ "(Saudi) of course! It is an honour to have you here!".

Baheeg: يا أخي لا تكبر الموضوع ده قميص! نزل ايدك /ya ?axi la tikabarilmawdûc da ?amîs nazzil ?idak/ " Come on , man ! It is just a shirt! What a suck up".

This scene contains two Egyptian colloquial fixed expressions that need extra attention in subtitling as they greatly pose difficulties in translation. The first fixed expression is هرشت الليلة/harašt-lailah/ (lit. you understood the night?) which is highly culture-bound Arabic colloquialism having no equivalent idiomatic form in the target language. Idiomatically, this expression refers to addressee's ability to grasp what is being said or communicated or the intended message on the part of the addresser. In such a context, this expression هرشت الليلة؟؟ /harašt-lailah/ is used in interactional situations between speech participants as an interrogative mood to inquire the addressee's comprehensibility of the locution being uttered or not or whether he got a penny of the speaker's thought or not. It can be added that there is another Arabic colloquial fixed expression that displays the same metaphorical and idiomatic expression, that is, هرشت دماغك /harašt dimâgak/. Idiomatically speaking, this expression is equivalent to 'I read your mind', 'I get what is going on in your mind', and 'I get at what you are saying'. In both fixed expressions, the word /harašt/ is used metaphorically and idiomatically to denote "understanding and grasping the content of something".

The subtitler provides "you with me ?" as an equivalent subtitling for the fixed expression هرشت الليلة /harašt-lailah/ which is far from the intended meaning of the Arabic fixed expression. It does not also 
satisfy the TT viewer's interest to be aware of the Arabic socio and cultural meaning of this idiom. A more reflective subtitling can be proposed as 'did you read my thought?' or 'did you read my mind?', which can adequately convey the cultural and situational meaning of this Arabic expression.

The second fixed expression is تكبر الموضوع/la tikabarilmawdûc/ which literally means (do not make the issue that bigger).This combination is employed in situations to idiomatically refer to over-reactive behaviors or actions that are treated as if they were serious when in fact they are not. It also indicates an exaggeration or putting too much focus on a minor issue and making it seem like a major issue or more important than it really is. Generally and culturally speaking, this fixed expression is usually used when a person makes out of a trivial issue or a problem a major one. It is usually based on the concepts of exaggeration and overstatement.

The subtitler did not pay attention to subtitling /a tikabari-lmawdûs/ and dropped its translation through following deletion strategy. In this context, deletion or omission is realized at sentence level, i.e. the whole fixed expression was deleted (Schjoldager, 2008). This deletion considerably and negatively affects the intended message by overlooking the essential cultural aspects of this expression. Neither does this dropping contribute to the success of the screen translation nor help the viewer to assimilate the image of the Arabic culture in depicting unimportant or marginal issues as major or basic ones. Therefore, the subtitler had to televise the subtitling of this well-established Arabic colloquial idiom. Alternative subtitles can be formulated to suit well in this context such as the target language idiomatic form 'do not make a mountain out of a molehill'. This subtitling largely adds to the contextual meaning and can be valid counterpart for the Arabic fixed expression. Other equivalents can be suggested for this idiom as 'do not make a drama out of it' and 'it is no exaggeration'. 


\section{Example 2}

Beggar to Baheeg: .... وغير إن رجليا فيها غرغرينا والواد لماوقع من

/wi gayr ?in riglayya fiha gargarîna wilwâd lama wi?is min .../"Not to mention that I have gangrene on my leg and when my kid fell..."

Baheeg: كفاية خلاص إنت ققلتلي اليوم بدرى بدرى /kifâya xalâs ?inta ?afaltili-lyûm badri badri/ "ENOUGH. No more, you 've just shut down my whole day!".

This is a dialogue between Baheeg and a beggar seeking Baheeg's financial help owing to his bad and difficult circumstances that he is enumerating during this scene. This scene contains one of the most familiar Egyptian colloquial expressions that is usually used informally إنت قفلتلى اليوم/inta ?afaltili-lyûm/ (lit. you blocked my day). In the Arabic culture, this fixed expression refers to pessimism and bad omen that a person feels as a result of seeing, talking to and dealing with certain people. This is usually linked to the speaker's anger that something will go wrong with his day or something unpleasant is forthcoming. Metaphorically speaking, this expression is closely equivalent to causing someone's day off or making him يوم completely out of mood. Arabs customarily use the expression قافڤ /yûm ?âfil/ to express the difficulties or problems that may arise out of the blue and that may render normal course of the day impossible. Similarly, such an expression is utilized in situations where there are no prospects of success or good luck that a person may experience due to other people's behaviors or deeds.

The subtitling that has been given to the expression إنت قفلتلى اليوم /?inta ?afaltili-lyûm/ is "you 've just shut down my whole day". This subtitling is too literal to convey the idiomatic and metaphorical meaning and prohibited the TT viewer from knowing the pragmatic effect of this popular Arabic expression. Moreover, the TT viewer may not grasp the scene perfectly out of this subtitling. Literal 
subtitling in this context completely falls short of the cultural and metaphorical connotations of this colloquial expression as it is not properly or culturally contextualized. This fixed expression could be subtitled in other ways that seem more relevant to its idiomatic meaning such as 'you made my day off', 'you ruined my day', 'you did not make my day' and 'lack a day!'. These proposed subtitles echo the original text and reflect the sociocultural flavor of this Arabic colloquialism.

\section{Example 3}

Baheeg to Mared:شَّuft ?inta bitiţâmil maça-l?umniyât bistihtâr ?izây/ " See how you're so irresponsible with wishes!".

Baheeg: با ابنى مش ده مشروع تخرجك ولا إنت بتشتخلى؟ /ya ?ibni miš da mašrû graduation project or you are messing with me?".

This particular scene contains an Arabic colloquialism that we often encounter in our everyday conversation, i.e. إنت بتشتظفنى /?inta bitištagalni/ (lit. are you working me?). In this scene, Baheeg uses this fixed expression as a denial to what the other speech participant is trying to impute to him. In Arabic culture, this idiom usually expresses skepticism on the part of the addressee about what is being communicated to him by the addresser. It can also be used in situations in which the speaker is persuading the hearer to believe what is really not or lacking rational evidence. Idiomatically, the locution إنت بتشتغلنى? Inta bitištagalni/ has equivalent connotations to 'pulling someone's leg', 'kidding someone' and 'trying to mock someone'. The translation of this locution must take this contextual meaning into account.

The subtitling given to إنت بتثنتخنى? / inta bitištagalni/ is "are you messing me?". The subtitler does not seem to follow a specific 
strategy in translating this expression. This translation falls short of the metaphorical and idiomatic meaning of this Arabic-idiomatic expression. The phrasal verb the subtitler provides "mess with" is used in situations under the meanings of: to cause trouble for someone, to deal with someone in a way that may cause anger or violence and to tamper or play with something in a careless way. These aspects of meaning have nothing to do with the screen expression inta bitištagalni/ and do not reflect the sociocultural orientations of this fixed expression. This phrasal verb semantically revolves around the idea of tampering with someone or something in a way that results in anger or turning upside down.

It is noted that the same fixed expression إنت هتثنتلنى / inta hatištagalni/ was used for a second time by Baheeg to a waiter on another scene of the film. The subtiltler provides another translation this time, namely, "What, are you trying to play me". Still, this subtitling lacks a proper equivalence to the source text as the subtitler overlooks completely the idiomatic and metaphorical meaning of the Arabic locution. This also shows that the subtitler is wavering between subtitling this expression in its two occurrences. This reveals the subtitler's unawareness of the contextual and idiomatic meaning of this expression. Therefore, better subtitles should be suggested for this fixed expression to convey the intended meaning such as 'are you pulling my leg?', 'are you pulling my chain?', 'are you mocking me?', 'are you jerking my chain?', and 'are you playing with my mind?'. These subtitles are relevant to the Arabic colloquialism and help the viewer to understand the contextual meaning of this locution .

\section{Example 4}

A woman acting as Baheeg's bride:أنا الى كنت فاكر اك هتتغير بعد الجواز /?ana ?ili kunt fakrâk hatitgayar baçdi-gawâz / "And here I thought you would change after marriage". 
/saћîh daili-lkalb sumruh ma hayitcidil/ "But it is true what they say. You can't teach an old dog new tricks".

One of the most widely circulated swear words this particular scene displays is the colloquialism ديل الكلب عمره ما هيتعدل/daili-lkalb sumruh ma hayitçidil/ (lit. the dog's tail will never go straight). Culturally speaking, this colloquial swear word is considered an insulting term used impolitely to say about the person you are addressing. Such a colloquial expression is addressed to those who are usually blamed for sticking to their old habits or behaviours that proved contrary to normal modes of actions or ethics. It can be added that this idiom is used in situations in which somebody is advised to abandon doing things or bad habits in a certain way that he cannot or shows no willingness to change. This prompts us to say that this Arabic fixed expression is more pertinent to negative contextual situations than positive ones when some people find it impossible or hard to deviate from their usual behaviours. Idiomatically, this expression is equivalent to 'you cannot make others alter their habits', and 'someone who has a life-time bad behavioural pattern, so it is not easy to teach them to assume a fresh track'.

The Arabic expression in question was subtitled as "You can't teach an old dog new tricks". It seems that the subtitler adopted transfer strategy in translating this fixed expression. The subtitler resorts to translating this idiom by following using an idiom of a similar meaning but with dissimilar form. This means that he/she uses "an idiom or a fixed expression in the target language which has a similar meaning to that of the source idiom or expression, but which consists of different lexical items". (Baker, 1992, p. 74). This target language idiomatic expression may convey the context and cultural aspects of ديل الكلب عمره ما هيتعدل/daili-lkalb sumruh ma hayitcidil/. The idiom "You can't teach an old dog new tricks", as Collins COBUILD Dictionary of Idioms (1995) puts it, is used in the 
sense of "it is often difficult to get people to try new ways of doing things, especially if these people have been doing something in a particular way for a long time". This subtitling is fairly acceptable since it might reflect the connotation of the original text. However, a more indicative idiom that clearly and sufficiently conveys the cultural meaning of the Arabic fixed expression in question is 'a tiger (a leopard) cannot change its spots' or 'a tiger cannot change its stripes'. This is a rather negative combination which indicates that one's nature, once ingrained, will not be altered forever. This idiom is, according to Webster's Ninth New Collegiate Dictionary (1990), "used to say that people cannot change their basic personalities, habits, etc.". The same contextual connotation of this idiom is displayed by The American Heritage Dictionary of Idioms (1997) where it is used to mean "one can't change one's essential nature". Thus, this idiom strongly implies that things cannot change their innate nature and suggests that people who get used of doing bad habits show no signs or intentions of change. Further suggested subtitles that could echo the same cultural and metaphorical connotations of the colloquial Arabic expression are 'an ape's an ape a varlet's a varlet; though they be clad in silk or scarlet' and 'remove an old tree and it will wither to death'.

\section{Example 5}

Mared to Baheeg: أنا قررت أساعدك / a?na qarrart ?asâçdak / "I 've decided to help you".

Mared: أنا جيبتلك حتة دين فكرة /?ana gibtilak hitit dîn fikra/ "I 've got one hell of an idea !".

\section{إبام الغراب لأمه:Bâma gâbi-lgurâb lummu/ "I haven't heard that before!".}

Having a look on the above example reveals that it is a conversational bit between Mared and Baheeg in which the latter 
was suspicious of the former's abilities to come up with a useful idea that can help him achieve his dreams. This is clearly expressed at the level of the colloquial fixed expression used by Baheeg, i.e. ياما جاب /yâma gâbi-lgurâb lummu/ (lit. oh what a raven brought to his mother?). This is one of the most widespread Arabic colloquial swear words used in all circles of life and that may result in subtitling problems as it only belongs to Arabic culture, and specifically to the Egyptian culture. In the Arabic culture, the word 'raven' often augurs misfortune and bad omen so that it is mostly used in statements implying negative connotations. It is linguistically important here to shed light on the etymology of this expression and the reason why the word 'raven', which has a large share of heritage stories since the beginning of creation, was particularly stated in this expression. The origin of this colloquial idiom goes back to a team of researchers who conducted a study concluding that ravens pick up all things that shine in the sun. When investigating the hideout of the ravens, they found that the hideout contains worthless pieces such as a broken mirror, cup hand, a piece of tin, another of metal and other trivial things that have no value except that they shine in the sun. It was also observed that the matters collected by the ravens contain no useful food or no essential matters in form. Hence, comes the ياما جاب الغراب connotative implications of the colloquial expression لأمه /yâma gâbi-lgurâb lummu/. Culturally and idiomatically, this Arabic expression is a crude locution said to someone who brings you gifts or things you do not like or objects being viewed as worthless. It is also used in situations where a person providing someone else with a certain thing imagines that it is an amazing and unprecedented thing that will cause happiness to the other person.

Strangely, the subtitler translated this swear word as "I haven't heard that before!" which seems odd to this particular context as it is idiomatically and culturally irrelevant. This subtitling simply sacrifices the sociocultural aspects of this crude expression. In order to make up for this translational inadequacy and loss of the intended subtitling, this colloquialism should be given a subtitling that can be 
similar or close to the contextual situation such as 'you have brought some crap with you', 'what a crap' and 'what a useless thing!'. These suggested subtitles echo the original text and are linguistically and culturally adequate, especially with the use of words 'crap' and 'useless' that carry the idea of worthlessness and futility.

\section{Example 6}

The office man called Noshy:

$$
\text { يا إبنى اكبر بقى وبطل لعب العيال بتاعلك ده طلعت عين أمى }
$$

/ya bni ?ikbar ba?a wi battal lişbi-lçiyâl bitâcak dah tallaşt sain ?ummi/ "Grow up son! And stop these childish antics of yours, I 've had enough !"

Baheeg: أنا أسف يا عم نصحى أنا كنت بضحك معاك? /ana ?âsif ya ̧am Nushi ?ana kunt badahћak maşâk/ "I 'm sorry uncle Nozhy. I was just playing with you".

This scene is a conversation between the office man in the veterinary hospital named Noshy and Baheeg who used to be kidding with Noshy where he usually got panic owing to Baheeg's joyful tactics. In this particular scene, Noshy has outspoken his anger and that he will not put up with such childish tactics anymore. He used the colloquial swear word طلعت عين أمى/tallast cain ?ummi/ which literally means (you popped out my mother's eyes). This expression is also used as a rude expression said about someone who is getting used to bothering and annoying other people with his antics. Idiomatically, this expression is characterized by being an insulting term that is usually connected with negative situations. To put it simpler, the person to such a swear word is addressed goes to extreme limits or overstepped the mark in dealing with others in this manner that they no longer show patience or fortitude with him. Metaphorically speaking, the swear word in question is best interpreted or may by equivalent to 'I am fed up', 'you gave me hard 
times' and ' I can no longer put up with you'. These metaphorical طلعت aspects can be displayed by another similar Arabic swear word /tallaşt rûhi/.This expression has almost the same contextual meaning but with slight lexical differences to the swear word in this film scene.

The swear word طلعت عين أمى/tallast cain ?ummi/ may pose a difficulty in translation on the grounds that it is Arabic-specific and has no corresponding form in the target language. This expression was subtitled as "I 've had enough". The strategy the subtitles adopts in translating this expression is paraphrase strategy which can be resorted to "when a match cannot be found in the target language or when it seems inappropriate to use idiomatic language in the target text because of differences in stylistic preferences of the source and target languages" (Baker, 1992, p. 74). This subtitling by paraphrasing is acceptable but it does not convey all the essential components of meaning of being annoyed or disgusted by someone's behaviours especially for a long time. In addition, this subtitling does not clearly and sufficiently indicate the idea of getting bored or disappointed by someone or something that one has experienced for too long. In order to convey a full communicative load of this swear word, a better and a more indicative subtitling may be formulated as 'I am so fed up'. This suggested subtitling adequately reflects the cultural aspects of this colloquialism since it implies the duration of annoyance and boredom experienced by someone towards somebody else. The phrasal verb "fed up", as Webster's Ninth New Collegiate Dictionary (1990) notes, means "tired, sated, or disgusted beyond endurance". Thus, it suits well in this context and echoes the contextual meaning of this Arabic colloquial swear word.

\section{Example 7}

Shrief: الله يخرب بيتك زي ما خربت بيتي وطلقتني /allâh yixrib baitak zay ma xarabt baiti wi tal?tini / "God dam you man, you 've ruined my life and my marriage". 
Baheeg:كunt bitkallim mirâtak ?aћsan tistâhil/ "Oh you were talking to your wife? Good, you deserve that".

Baheeg: عشان إنت رجل خلبوص وعايز شد أذنيك / çašân ?inta ragil xulbûs wi çâyiz šadd ?uzunaik/ "Because you are a womanizer and need a slap on the wrist".

Considering example 7, Baheeg is taking to his colleague Sherief blaming and criticizing him for his multiple female relationships and trying to persuade him to change this behavior he was engaged in for a long time. In this scene, while Sherief is having a phone call with his wife Baheeg intervened and remind Sherief of his affair the day before so loudly that this came to his wife's hearing and consequently asked her husband for divorce. Sherief is always advised by Baheeg to abide by ethical code of behavior and to get rid of this bad habit to preserve his family relationship. Baheeg used the colloquial Arabic expression عايز شد أذنيك/câyiz šadd ?uzunaik/ which literally means (your ears need to be pulled). Culturally speaking, this is a crude fixed expression said to someone who is rebuked for refraining from his unpleasant and bad conduct that is socially and ethically unacceptable. Idiomatically and metaphorically, this Arabic fixed expression refers to a mild and moderate punishment that functions as a deterrent to someone to prevent him from doing his long-standing habits. It must be added that the idea of punishment implied by this Arabic expression is not of a harsh or severe nature but it is characterized by being a warning or reprimand. In other words, the expression عايز شد أذنيك/câyiz šadd ?uzunaik/ is deserved only in habits or activities that are not of a gruesome nature to show disapproval of something committed. It does not involve any pain or physical harm.

As for the translation of the Arabic colloquial expression عايز شد أذنيك / أنâyiz šadd ?uzunaik/, the subtitler provides "need a slap on the wrist". The strategy the subtitler follows in subtitling this expression is partial equivalence. This strategy involves transferring a source 
text idiomatic expression into its equivalent target text idiom which carries the same meaning but with a different form. As it has been already explained, it is possible to find an idiomatic form in the target language which has a similar meaning to that of the source language considering the fact that the two idiomatic forms have different lexical items. The subtitler manages to echo the idiomatic and metaphorical meaning that is greatly matching the sociocultural aspects of the Arabic expression. It means, according to The American Heritage Dictionary of Idioms (1997), "a mild reproof". A similar meaning of the same English combination is stated by Collins COBUILD Dictionary of Idioms (1995) as "you can refer to a very light punishment or reprimand as a slap on the wrist". Therefore, the target language idiomatic form "need a slap on the wrist" has almost the same connotative meaning as the source language form and reflects the Arabic culture-idiomatic meaning. Another suggested subtitling that could match the original text message is 'you need to be called on the carpet' which means scolding, rebuking or criticizing someone for doing something wrong. 


\section{Conclusion}

The data analyzed reveal that fixed expressions and swear words are highly culture-specific linguistic phenomena that pose challenges and difficulties in translation. These difficulties turn out to relate either to the subtitler's ability to subtitle the idiom accurately or his successful choice of the most indicative equivalent in the target language. In order to overcome cultural gaps between languages, subtitling strategies and mechanisms have been suggested throughout this paper other than those the subtitler resorted to.

The present paper shows that some subtitles have been completely dropped from translation by following deletion or omission strategy. This would result in loss of essential components of the source language messages especially in relation to those Arabic cultures and images that should be highlighted and transferred in subtitling. In case there is no equivalent in the target language that matches the source language text, the subtitler should not drop this out of subtitling but should try hard to find mechanism or strategies to clarify or elaborate on the original expressions and make the meaning understandable to the TT viewers. Although deletion may be justifiable in some cases related to stylistic considerations or cultural variations, the subtitler must do his/her best to subtitling everything on the grounds that the deletion strategy in this regard is deemed as a loss and sacrificing of important Arabic cultural aspects.

Throughout the data analysis, it has been observed the subtitler provides a literal mechanism of fixed expressions in many cases which was functionally improper where the idiomatic and pragmatic illocutionary force were totally lost. Literal translation not only affects the figurativeness and idiomaticity of fixed expressions but also their cultural specificity. The paper concluded that three more strategies are suggested to solve the problems discussed in this study. These include paraphrase strategy which offers translation 
solutions where it is usually applied in cases of stylistic variations between the source and target languages. This proved acceptable in cases when the subtitler had a difficulty in finding corresponding idiomatic forms in the target language to convey the meaning of the source text idioms. When the subtitler follows paraphrase strategy due to linguistic and social peculiarities of the original text, he/she should keep preserving the pragmatic effect of the original text in subtitling. This strategy is best utilized in idioms which are less culture-specific than others.

Secondly, total equivalence strategy which allows the subtitler to use an expression with similarly equivalent lexical items and a similar meaning in the target language. Nevertheless, a close match in form and meaning between the source text and the target one is of a limited scale in view of the fact that the data analyzed are mostly source-language bound linguistic phenomena. Thirdly, partial equivalence strategy which means using an expression with the same meaning but with different lexical items or dissimilar form. This is commonly used in this study successfully either by the subtitler him/herself or by suggesting alternative subtitles by the researcher. 


\section{Works Cited}

Al Abwaini, S. M. (2013). Problems that translators face when they subtitle culturally-bound expressions from English into Arabic ( M.A. thesis). Middle East University, Amman, Jordan. Retrieved from http://meu.edu.jo.

Ammer, C. (1997). The American Heritage Dictionary of Idioms. Boston: Houghton Mifflin Company.

Baker, M. (1992). In Other Words: A Coursebook on Translation $\left(2^{\text {nd }}\right.$ ed.). London: Routledge.

Bartoll, E. (2004). "Parameters for the Classification of Subtitles". In Topics in Audiovisual Translation edited by Pilar Orero, 53-60. Amsterdam/Philadelphia: John Benjamins Publishing Company.

Catford, J. C. (1969). A Linguistic Theory of Translation. London: Oxford University Press.

Collins COBUILD Dictionary of Idioms: Helping learners with real English.(1995). The University of Birmingham: HarperCollins Publishers.

Diaz Cintas, J. (2006). "Audiovisual Translation in the Third Millennium". In Translation Today: Trends and perspectives edited by Gunilla Anderman \& Margaret Rogers, 192-204. Beijin: Foreign Language Teaching and Research Press.

---- (2009).'Introduction-Audiovisual Translation: An Overview of its Potential". In New Trends in Audiovisual Translation edited by Jorge Diaz Cintas, 4-5. Bristol: Multilingual Matters.

Diaz Cintas, J. \& Remael, A. (2010) Audiovisual Translation: Subtitling. Manchester: St. Jerome Publishing.

Farb, P. (1981). Word Play. New York: Bantam.

Gottlieb, H. (1992). "Subtitling: A New University Discipline". In Teaching Translation and Interpreting: Training, Talent and Experience edited by Cay Dollerup, 153-160. Amsterdam /Philadelphia: John Benjamins Publishing Company. 
--- (1997). Subtitles, Translation \& Idioms. Copenhagen: University of Copenhagen.

--- (2005). "Subtitling". In Routledge Encyclopedia of Translation Studies edited by Mona Baker, 244-245. Shanghai: Shanghai Foreign Language Education Press.

Hawel, Z. S. (2019). "Strategies of Subtitling Swear Words in the Wolf of Wall Street Movie". Lark Journal for Philosophy, Linguistics and Social Sciences, 1-7 (34), 423- 432.The article available online at: https://www.iasj.net.

Kharabsheh, A. \& Yassin, O. (2017). "Translation of Colloquialism in the Arabic-into English Subtitled Film, The Dupes". International Journal of Comparative Literature and Translations Studies, 5 (3), 18-27. The Article available online at: https://www.resarchgate.net/publication/318793 $\underline{437}$

Koller, W. (1995). "The Concept of Equivalence and the Object of Translation Studies". Target- International Journal of Translation Studies, 7 (2), 191-122.

Larson, M. (1984). Meaning- Based Translation: A Guide to CrossLanguage Equivalence. Lanham, New York. London: University Press of America.

Leech, G. N. (1983). Principles of Pragmatics. Longman Inc: New York.

Longman Dictionary of Contemporary English. (1995). ( $3^{\text {rd }}$ ed). Longman Group LTD: RR Donnelly and Sons Company.

Makkai, A. (1972). Idiom Structure in English. The Hague: Mouton.

Nasser, M. N. (2019) "Cultural Difficulties of English Idioms Confronting Foreign Learners". Language in India, 19 (2), 316. The article available online at: https://www. researchgate.net/publication/331330179

Newmark, P. (1988). A Textbook of Translation. London: Prentice Hall.

Nida, E. A. (1964). Towards a Science of Translating. Leiden: Brill.

Nida, E. A. \& Taber, C.R. (1982). The Theory and Practice of Translation. Leiden: Brill. 
O'Connell, E. (2007). "Choices and Constraints in Screen Translation". In Unity in Diversity? Current Trends in Translation Studies edited by Lynne Bowker et al., 65-75. Beijin :Foreign Language Teaching and Research Press.

Paltridge, B. (2006). Discourse Analysis: An Introduction. London: Cornwall.

Perez Gonzalez, L. (2014). Audiovisual Translation. Theories, Methods and Issues. Routledge: New York.

Schjoldager, A. (2008). Understanding Translation. Denmark: Academic Publications.

Shuttleworth, M. \& Cowie, M. (2004). Dictionary of Translation Studies. Shanghai: Shanghai Foreign Language Education Press.

Toury, G. (1995). Descriptive Translation Studies and Beyond. Amsterdam/ Philadelphia: John Benjamins.

Webster's Ninth New Collegiate Dictionary. (1990). ( $9^{\text {th }}$ ed.) Springfield: Merriam Webster Inc. 


\section{Table of Phonetic Symbols}

The transcription symbols used in this study follow the IPA conventions. Following is a list of these Arabic symbols with some modifications for typing convenience.

\begin{tabular}{|c|c|c|}
\hline Symbol & Description & Examples \\
\hline$/ b /$ & Voiced bilabial stop & /bard/ "coldness" \\
\hline$/ t /$ & Voiceless alveolar stop & /talaf/ "ruin" \\
\hline $\mid \underline{t}$ & Voiceless alveolar emphatic stop & /tâlib/"student" \\
\hline$/ d /$ & Voiced alveolar stop & /dîn/"religion" \\
\hline$/ \underline{d} /$ & Voiced alveolar emphatic stop & /marad/"disease" \\
\hline$/ k /$ & Voiceless velar stop & /karam/"generosity" \\
\hline $\mid q /$ & Voiceless uvular stop & /qalb/ "heart" \\
\hline /?/ & Voiceless glottal stop & /?amr/ "order" \\
\hline$/ \mathrm{m} /$ & Voiced bilabial nasal & /madh/"praise" \\
\hline $\mid n /$ & Voiced alveolar nasal & Inahr/ "river" \\
\hline /l/ & Voiced alveolar lateral & /lawn/ "colour" \\
\hline $\mid r /$ & Voiced alveolar trill & /rayb/"doubt" \\
\hline $\mid f /$ & Voiceless labiodental fricative & /fann/ "art" \\
\hline /ठ/ & Voiced interdental fricative & /ðanb/ “sin” \\
\hline$/ s /$ & Voiceless alveolar fricative & /sabîl "way" \\
\hline$/ \underline{s} /$ & $\begin{array}{l}\text { Voiceless alveolar emphatic } \\
\text { fricative }\end{array}$ & /sabr/ "patience" \\
\hline $\mid z /$ & Voiced alveolar fricative & /zâ?ir/"visitor" \\
\hline $\mid \check{s} /$ & $\begin{array}{l}\text { Voiceless palato-alveolar } \\
\text { fricative }\end{array}$ & / ša?n/ "matter" \\
\hline $\mid g /$ & Voiced velar stop & /?agr/ "wage, pay" \\
\hline $\mid x /$ & Voiceless uvular fricative & |xayr/"goodness" \\
\hline$/ g /$ & Voiced uvular fricative & /garb/ "west" \\
\hline$/ \varsigma /$ & Voiced pharyngeal fricative & /sayn/ "eye" \\
\hline h/ & Voiceless glottal fricative & /fahm/“understanding" \\
\hline$/ \hbar /$ & Voiceless pharyngeal fricative & 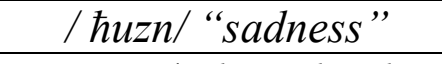 \\
\hline$/ w /$ & Voiced bilabial semi-vowel & /watan/ "homeland" \\
\hline
\end{tabular}




\begin{tabular}{|c|c|c|}
\hline$/ y /$ & Voiced palatal semi-vowel & /yusr/ "easiness" \\
\hline$/ \mathrm{i} /$ & $\begin{array}{c}\text { High front unrounded short } \\
\text { vowel }\end{array}$ & /min/ "from" \\
\hline$/ \hat{l} /$ & High front unrounded long vowel & /qașîr/ "short" \\
\hline$/ a /$ & $\begin{array}{c}\text { Low central unrounded short } \\
\text { vowel }\end{array}$ & /sabab/ "reason" \\
\hline$/ \hat{a} /$ & $\begin{array}{c}\text { Low central unrounded long } \\
\text { vowel }\end{array}$ & /qarâr/ "decision" \\
\hline$/ u /$ & High back rounded short vowel & $/$ kutub/ "books" \\
\hline$/ \hat{u} /$ & High back rounded long vowel & /nûr/ "light" \\
\hline
\end{tabular}

It is important here to shed light on some phonological processes used in transcribing Arabic sounds.

\section{Doubling:}

Doubling indicates elongation of consonants. Geminated consonants are indicated by doubling the symbols. Doubled consonants are pronounced longer than their short counterparts and with greater muscular efforts such as /rabb/ "lord", /sullam/ "ladder", and /farra/ "he fled away".

\section{Elision:}

Elision is concerned with the omission under certain conditions of the short vowels /a/, /i/ and /u/, on the one hand, and of /?/ on the other. Where elision occurs at the junction of words or within word, the feature is marked in transcription by a hyphen as in /kitâb?al tâlib / which becomes /kitâbu-țâlib/" the book of the student".

It is noted that some Arabic sounds in this study undergo phonemic variations according to the pronunciation system of the Egyptian colloquial Arabic. The Arabic sound (a) is symbolized as $\mathrm{Ig} /$ throughout the paper except in one case in which it is symbolized 
as $/ \mathrm{j} /$ as the case with standard Arabic as indicated in example (3) of the first film. The Arabic sound (ق) is pronounced in colloquial Arabic as a voiceless glottal stop /?/ unlike the only case symbolized as $/ q /$ in example (5) of the second film. Likewise, the sound $(\dot{j})$ is symbolized as $/ z /$ according to the way it is pronounced in the context of example (7) of the second film in contrary to the symbol /ð/ used in standard Arabic. 